\title{
Protein Catabolic Rate May Underestimate Dietary Protein Intake in Hemodialysis Patients
}

\author{
Jaime Uribarri \\ Department of Medicine, Mount Sinai School of Medicine, New York, N.Y., USA
}

\section{Introduction}

Protein catabolic rate (PCR) or its normalized value, nPCR, is widely used to define nutritional status in dialysis patients [1]. This term PCR obviously is a misnomer and refers to the net PCR since the total PCR is as high as $300 \mathrm{~g} /$ day and does not necessarily bear a relationship with protein intake [2]. In the steady state, the net PCR has to be equal to the dietary protein intake as long as the method to calculate PCR includes all the body nitrogen output.

The usual method to calculate PCR is from nitrogen appearance rate [3] based on a formula developed from a detailed study of 5 dialysis patients with very low residual renal function who were judged to be in nitrogen balance [4]. In this study, total nitrogen output from stool, urine and dialysate and urea nitrogen appearance rate were measured independently and the following regression equation, which included both terms, was developed: urea nitrogen generation $=0.154 \mathrm{PCR}-1.7$. The authors recognized that in dialysate, nitrogen contained in urea, creatinine and uric acid accounted for only about $94 \%$ of total nitrogen measured by the Kjeldahl method, and that the remainder $6 \%$, or about $1.4 \mathrm{~g}$ of nitrogen, could be in the form of amino acids. These losses of about $8.75 \mathrm{~g}$ of amino acids $(1.4 \times 6.25)$ are very similar to the losses of about $8 \mathrm{~g}$ of amino acids per treatment that were docu-

\begin{tabular}{ll}
\hline KARGER & ( 1999 S. Karger AG, Basel \\
Fax +4161306 1234 & 0028-2766/99/0822-0097\$17.50 \\
$\begin{array}{l}\text { E-Mail karger@karger.ch } \\
\text { www.karger.com }\end{array}$ & $\begin{array}{l}\text { Accessible online at: } \\
\text { http://BioMedNet.com/karger }\end{array}$
\end{tabular}

mented in the early 80 s by a different group of investigators in hemodialysis patients using conventional cellulosic membranes and glucose-free dialysate [5]. Moreover, this regression equation agreed very closely with the plot derived from data in nondialyzed patients with stable chronic renal insufficiency gathered independently by another group of investigators [6]. This latter equation, urea generation rate $=0.149 \mathrm{PCR}-1.2$, differed from the above formula only by the magnitude of the intercept on the Y-axis; of interest, this difference of about $0.5 \mathrm{~g}$ of $\mathrm{N}$ per day is numerically almost identical with the losses of about $8 \mathrm{~g}$ of amino acids per dialysis $(0.5 \mathrm{~g} /$ day $\times 7$ days divided by 3 , the number of dialysis per week $=1.16 \mathrm{~g}$ of $\mathrm{N} \times 6.25=7.3 \mathrm{~g}$ of amino acid per treatment).

Recently, several authors have documented a significant increase in the losses of amino acids and protein into the dialysate as the result of repetitive processing of dialyzers [7-10]. Thus, with the current use of high-flux dialyzers and with at least $80 \%$ of the dialysis units in this country practicing dialyzer reuse, this formula may not measure accurately PCR since a large amount of nitrogen loss, either in the form of amino acids or protein, is not included in this calculation. The purpose of this presentation is to demonstrate that the current method used to calculate PCR in hemodialysis patients may indeed underestimate this parameter and hence dietary protein intake [3].
Jaime Uribarri, MD
Department of Medicine, The Mount Sinai Medical Center
One Gustave Levy Place, New York, NY 10029 (USA)
Tel. +1 2122414060 , Fax +1 2123699330
E-Mail jaime.uribarri@smtplink.mssm.edu 


\section{Methods}

Review of all the literature reporting on the loss of protein and/or amino acids during hemodialysis.

\section{Results}

There were four reports which described the loss of protein and/or amino acids during hemodialysis and are detailed below [7-10]. Ikizler et al. [7] measured the losses of amino acids into the dialysate with three different membranes: low-flux cuprophane (Terumo T150), lowflux polymethylmethacrylate (Toray B2) and high-flux polysulfone (Fresenius F80) and found the following averages: $7.2 \pm 2.6,6.1 \pm 1.5$ and $8.0 \pm 2.8 \mathrm{~g}$ of amino acids per dialysis session respectively. When polysulfone dialyzers were studied at the 6 th reuse, an average loss of 12.2 $\pm 4.4 \mathrm{~g}$ of amino acids per dialysis occurred. Thus, these results suggest that currently available dialyzers, when first used, lose about the same amount of amino acids as those in the past; reuse to 6 times increases the losses by $50 \%$ and it is quite possible that further reuse will increase the losses of amino acids even further. The same group also measured albumin losses into the dialysate with increasing reuse number as follows: the average amount of albumin lost was $0.98 \pm 0.9 \mathrm{~g} /$ treatment (range $0-18 \mathrm{~g}$ ) below the 10th reuse, $1.94 \pm 1.5 \mathrm{~g}$ (range 03-8.6 g) for $10-14$ reuses, $4.3 \pm 3 \mathrm{~g}$ (range $0.5-9.4 \mathrm{~g}$ ) for $15-19$ reuses, $9.3 \pm 5.5 \mathrm{~g}$ (range 1.1-20.8 g) for 20-24 reuses and $11 \pm$ $7.9 \mathrm{~g}$ (range 1.1-25.6 g) for over 24 reuses. Bleach and formaldehyde were used to process dialyzers in this study.

Kaplan et al. [8] measured the dialysate protein losses from polysulfone dialyzers (F80) undergoing repetitive processing with bleach and formaldehyde. Mean total protein losses per treatment were: $1.2 \pm 0.3 \mathrm{~g}$ during the 1 st use, $1.8 \pm 0.3 \mathrm{~g}$ during the 5 th use, $2.9 \pm 0.4 \mathrm{~g}$ during the 10th use, $6.4 \pm 0.5 \mathrm{~g}$ during the 12th to 13 th use, 10.4 $\pm 1.1 \mathrm{~g}$ during the 16 th through 20 th use and $17.5 \pm 1 \mathrm{~g}$ during the $23 \mathrm{rd}$ through 25 th use. To further validate the results, dialysate samples were also evaluated for albumin concentration which went from unmeasurable for the 1 st and 5th use to $14.4 \pm 3.2 \mathrm{mg} / \mathrm{dl}$ after 23-25 reuses. In those samples where albumin and total protein were measured, the ratio of albumin to total protein was $53 \%$. A random sample of dialyzers processed without bleach revealed only minimal protein losses after repetitive reuses.

Kaysen et al. [9] in a study of mechanisms of hypoalbuminemia in hemodialysis patients reported albumin losses of up to $5 \mathrm{~g} /$ treatment with more than 10 reuses, up to $10 \mathrm{~g} /$ treatment for more than 20 reuses and up to $13 \mathrm{~g} /$ treatment for more than 30 reuses. The dialyzers were processed with bleach and formalin in this study.

Kirschbaum [10] reported a significant decline in serum albumin after conversion from low-flux to high-flux dialyzers in a large group of hemodialysis patients. Dialyzers were reprocessed with bleach and formaldehyde. He found that among 12 dialysates, the differences between total nitrogen and urea nitrogen averaged $29 \mathrm{mg} / \mathrm{l}$. Because the average dialysis session lasted $210 \mathrm{~min}$ and the dialysate flow was $500 \mathrm{ml} / \mathrm{min}$, the average loss of nonurea $\mathrm{N}$ was $3 \mathrm{~g} /$ dialysis $(29 \mathrm{mg} / \mathrm{l} \times 105 \mathrm{l})$, which would correspond to a protein or amino acid equivalent of $19 \mathrm{~g}$ /dialysis! $(3 \times 6.25)$. The drop in serum albumin was most likely the result of negative nitrogen balance induced by excessive losses in the dialysate although the author states that he did not detect protein in the dialysate using a pyrogallol red reagent [10].

\section{Discussion}

The four studies discussed in the above section suggest that a significant amount of nitrogen, either in the form of amino acids or protein, is actually lost during hemodialysis using high-flux dialyzers that have been processed with bleach and formaldehyde. In other words, there are enough reasons to suspect that we may indeed be underestimating the total nitrogen output with our current calculation of PCR during hemodialysis. If we take a patient who is being dialyzed for the 23 rd time with the same polysulfone dialyzer, loss of protein may be $10.4 \mathrm{~g}$ (using Kaplan's data) and extra losses of amino acids are at least $4 \mathrm{~g}$ (using Ikizler's data); these losses represent an extra $15 \mathrm{~g} /$ dialysis or $6.5 \mathrm{~g} /$ day $(15 \mathrm{~g} \times 3 / 7)$, which are not accounted for in the current calculation of PCR. If the losses of amino acids increase significantly after the 6th reuse, say to $16 \mathrm{~g}$ /dialysis, this extra loss of nitrogen may become very significant, as much as $19 \mathrm{~g}$ of protein equivalents per dialysis or $8.1 \mathrm{~g} /$ day in the previous example. Thus, a hemodialysis patient who uses dialyzers processed with bleach and formaldehyde can be losing as much protein per day as the counterpart CAPD patient [11]. This fact has not been widely appreciated in the literature and has been completely ignored in the current methods used to calculate PCR.

As mentioned above, these significant losses of extra nitrogen into the dialysate are not being detected by our current estimate of PCR based on the nitrogen appear- 
ance rate and the Borah's equation [4]. At first hand, it may appear that the problem is solved by methods of calculating PCR by direct urea nitrogen quantification in the dialysate [12], but this is not the case, because these methods only measure the output of urea nitrogen not of total nitrogen; the relationship between urea nitrogen generation and PCR is calculated from other regression formula obtained from stable nondialyzed renal failure patients who 'are not losing extra nonurea nitrogen in the dialysate' [13]. An obvious solution to this problem would appear to be the determination of a new formula to estimate PCR by measuring total nitrogen output and urea nitrogen appearance rate independently in a group of patients who are reusing dialyzers. The problem with this approach is that the loss of nitrogen into the dialysate is variable, depending on the number of reuses and the reuse method. For example, processing of dialyzers with heat and heat plus citric acid [14] and peracetic acid [15] does not seem to be accompanied by increased losses of protein into the dialysate in contrast to processing with bleach and formaldehyde. Moreover, Kaplan et al. [8] showed that dialyzer reprocessing using formaldehyde without bleach prevented the increased loss of protein. From this perspective the problem does not have a practical solution unless a different constant is added to the calculation of PCR in each dialysis unit based on the average reuse, mode of reuse and information taken from the literature [7-9].

On the other hand, the degree of underestimation is not much, about $0.1 \mathrm{~g} / \mathrm{kg} /$ day or $10 \%$ less, on the average 70-kg patient and it could be ignored. Unfortunately, the main problem is that these losses are variable from dialysis unit to dialysis unit and within the same patient depending on the number of reuses. What is very clear, however, from the above analysis is that nPCR, as it is currently calculated, cannot be completely equated with dietary protein intake.

This discussion has completely ignored the possible urinary losses of nitrogen because hemodialysis patients as a group lose residual renal function very fast. However, in patients who are recently starting on this therapy, the urinary losses of nitrogen may be significant and may lead to underestimation of the true PCR. We have also ignored the small losses of nitrogen through the skin and breathing since every study dealing with this issue has ignored them; it is possible that these losses of nitrogen may be higher in dialysis patients than in normals given their much higher body concentration of nitrogen. We have not discussed, since they apply only to estimating urea generation from urea kinetic modeling, the possible errors associated with the calculation of this parameter, namely, the effect of time of sampling of the postdialysis BUN and the use of an estimated rather than a measured volume of distribution of urea [3].

In summary, we still believe that PCR is a very useful tool to approximately determine the daily protein intake of dialysis patients. We should keep in mind, however, that this parameter, as is currently calculated, may underestimate true dietary protein intake.

\section{References}

1 Acchiardo SR, Moore LW, Latour PA: Malnutrition as the main factor in morbidity and mortality of hemodialysis patients. Kidney Int 1983;24(suppl 16):199-203.

2 Gilham B, Papachristodoulou DK, Thomas JH (eds): Nutrition: proteins; in Wills' Biochemical Basis of Medicine. London, Butterworth/ Heinemann 1997; pp 142-144.

3 Depner TA: Prescribing Hemodialysis: A Guide to Urea Kinetic Modeling. Boston, Kluwer Academic, 1991.

4 Borah MF, Schoenfeld PY, Gotch FA, Sargent JA, Wolfson M, Humphreys MH: Nitrogen balance during intermittent dialysis therapy of uremia. Kidney Int 1978;14:491-500.

5 Wolfson M, Jones MR, Kopple JD: Amino acid losses during hemodialysis with infusion of amino acids and glucose. Kidney Int 1982;21: 500-506.

Intake in HD Patients
6 Cottini EP, Gallina DL, Dominguez JM: Urea excretion in adult humans with varying degrees of kidney malfunction fed milk, egg or an amino acid mixture: Assessment of nitrogen balance. J Nutr 1973;103:11-19.

7 Ikizler TA, Flakoll PJ, Parker RA, Hakim RM: Amino acid losses during hemodialysis. Kidney Int 1994;46:830-837.

8 Kaplan AA, Halley SE, Lapkin RA, Graeber CW: Dialysate protein losses during bleach processed polysulphone dialyzers. Kidney Int 1995;47:573-578.

9 Kaysen GA, Rathore V, Shearer GC, Depner TA: Mechanisms of hypoalbuminemia in hemodialysis patients. Kidney Int 1995;48:510516.

10 Kirschbaum B: The decline in serum albumin after conversion to high flux, high effective dialysis. Artif Organs 1994;18:729-735.

11 Uribarri J, Dimaano F, London RD, Dowling $\mathrm{J}$, Marcus RG: Increase in $\mathrm{Kt} / \mathrm{V}$ increased se- rum albumin but not $\mathrm{nPCR}$ in a group of patients on continuous peritoneal dialysis. Perit Dial Int 1997;17:3-5.

12 Charytan C, Gupta B, Meindel N, Spinowitz B: Fractional direct dialysis quantification: A new approach for prescription and monitoring hemodialysis therapy. Kidney Int 1996;50:18451849.

13 Maroni BJ, Steinman TI, Mitch WE: A method for estimating nitrogen intake of patients with chronic renal failure. Kidney Int 1985;27:5865.

14 Levin NW, Parnell SL, Prince HN, Gotch F, Polaschegg HD, Levin R, Alto A, Kaufman AM: The use of heated citric acid for dialyzer reprocessing. J Am Soc Nephrol 1995;6:15781585.

15 Rockel A, Hertel J, Fiegel P, Abdelhamid S, Panitz N, Walb D: Permeability and secondary membrane formation of a high flux polysulfone hemofilter. Kidney Int 1986;30:429-432. 